IZA DP No. 8185

\title{
The Gender-Career Estimation Gap
}

Lutz C. Kaiser

May 2014 


\title{
The Gender-Career Estimation Gap
}

\author{
Lutz C. Kaiser \\ North Rhine-Westphalia University of Applied Sciences for Public Administration, \\ DIW and IZA
}
Discussion Paper No. 8185
May 2014

IZA

P.O. Box 7240

53072 Bonn

Germany

Phone: $+49-228-3894-0$

Fax: +49-228-3894-180

E-mail: iza@iza.org

Any opinions expressed here are those of the author(s) and not those of IZA. Research published in this series may include views on policy, but the institute itself takes no institutional policy positions. The IZA research network is committed to the IZA Guiding Principles of Research Integrity.

The Institute for the Study of Labor (IZA) in Bonn is a local and virtual international research center and a place of communication between science, politics and business. IZA is an independent nonprofit organization supported by Deutsche Post Foundation. The center is associated with the University of Bonn and offers a stimulating research environment through its international network, workshops and conferences, data service, project support, research visits and doctoral program. IZA engages in (i) original and internationally competitive research in all fields of labor economics, (ii) development of policy concepts, and (iii) dissemination of research results and concepts to the interested public.

IZA Discussion Papers often represent preliminary work and are circulated to encourage discussion. Citation of such a paper should account for its provisional character. A revised version may be available directly from the author. 


\section{ABSTRACT}

\section{The Gender-Career Estimation Gap}

The paper discusses gender differences with regard to the self- and reciprocal estimation of career expectations. Firstly, the theoretical background and the literature are identified. Within this frame, the instance of self-under-estimated career prospects of female workers and statistical discrimination in the labor market are described. Both aspects are jointly assessed as a self-fulfilling prophecy-phenomenon redounded to women's disadvantage on the labor market. Secondly, the empirical part analysis the respective self- and reciprocal estimation of female and male career prospects for public sector workers in Germany. The results display obvious discrepancies between self- and reciprocally estimated career expectations that constitute a gender-career estimation gap. As the German public sector contains specific devices to equalising career chances of male and female employees, the findings even underpin the insistency of under-estimated career prospects of female workers despite the existing public sector regime of equality. Finally, approaches of how to equalize male and female career chances are critically reviewed.

JEL Classification: J16, J24, J4, J71, J78

Keywords: self- and reciprocal estimation of career opportunities, self-fulfilling prophecy, gender-career estimation gap, statistical discrimination, public sector

Corresponding author:

Lutz C. Kaiser

North Rhine-Westphalia University of

Applied Sciences for Public Administration

Thürmchenswall 48-54

50668 Köln

Germany

E-mail: lutz.kaiser@fhoev.nrw.de 


\section{Introduction}

Over the entire professional life, gender differences in self-estimated career expectations can be rated as predictors for differences in the development of male and female career profiles. In the following, this hypothesis is investigated in sight of several aspects of career expectations. Section 2 displays theoretical aspects and the identification of these gender effects in the relevant literature. Section 3 implies the empirical strategy to exhibit self-estimated and reciprocally estimated career expectations of female and male public sector workers in Germany, resulting in the identification of a gender-career estimation gap. In particular, an observation of differences in the reciprocal judgement of career chances (men in respect to women and vice versa) could lead towards a better understanding of gender related differences in career chances. Additionally, the self- and reciprocal estimation of career expectations in the German public sector is an excellent field of research, since one may expect comparatively minor gender differences in this respect due to various legal devices to guarantee equal career chances. However it has to be admitted, that the paper contains the drawback of a missing comparison to the private sector of the economy to test for presumably differences in the magnitude of a gender bias in career chances and statistical discrimination between both sectors of the economy. Section 4 describes the data as the basis for the empirical analysis that is established in section 5 . Section 6 concludes and discusses remedies in terms of handling gender related differences in the self- and reciprocal estimation of career expectations. ${ }^{1}$ Finally, section 7 outlines further research options.

\footnotetext{
${ }^{1}$ For the progress of this paper, the author appreciates very valuable and helpful comments of Elke Holst, Research Director for Gender Studies at the German Institute for Economic Research (DIWBerlin).
} 


\section{Theoretical Background and Literature Review}

This section describes the key theories and gives an overview of existing literature with regard to the field of self-estimation of career opportunities and the reciprocal estimation of career opportunities. As a starting point, both, a self-estimation of one's own career prospect or, in a converse perspective, a reciprocal estimation of career opportunities of another person contain a forecast-approach; career prospects in diverse negative, positive or neutral ways have to be qualified.

However, what is the basis of this forecast? Here, the term reciprocal can be utilized from a different, i.e. the psychological angel. According to Bandura (1997), the so-called reciprocal determinism is an approach that explains individual behaviour by means of two main perspectives that mutually coincide. On the one hand, individual's behaviour is shaped by the social environment. However, on the other hand, individual's behaviour simultaneously shapes the social environment with this social environment shaping (again) individual behaviour.

The latter assumption could be translated as 'You get what you are'.2 Certainly, individual professional career tracks are shaped by the professional environment, e.g. firm-specific hiring procedures or promotion opportunities within companies. However, this professional environment is partially a copy of the signals sent by the individual workforce during hiring or promotion processes, co-formed e.g. by the individual self-efficacy to be successful in hiringand/or promotion-processes. Within labor markets, this aspect could be labelled as supply-side confidence or employee’s self-efficacy.

\footnotetext{
${ }^{2}$ An interesting experiment with regard to gender related differences in maths performance is a good example of this assumption (Spencer et al. 1999). As compared to men, women may possess lower selfestimated competences in maths on average. However, if it was explained to the experiment candidates in advance of the test, that women are said to have less competences in maths than men, but this is not valid for the following tests in the experiments, women and men performed with the same test results. Hence, so to speak, gender related differences in self-estimated competences were equalized by simply announcing equality.
} 
For the purpose of this analysis, the concept of reciprocity is used in a somewhat extended way. In a first stance, the self-estimation of career opportunities, either with regard to male or female workers, constitutes one part of the reciprocal determinism. An additional part is due to the genuine reciprocal estimation of career chances of the respective opposite sex, i.e. males in terms of females and vice versa. Both parts coincide towards an important key factor with regard to the configuration of career chances.

These assumptions are important in terms of the topic 'well-being of working women'. As long as self- and reciprocal beliefs in career opportunities are equally distributed among male and female workers, e.g. based on a same specific level as 'good' or 'bad', there may not exist an intervening gender bias with regard to career development processes. For this scenario the above mentioned reciprocal determinism equally affects male and female career profiles.

However, divergences between these self- and reciprocally evaluated prospects, the so-called gender-career estimation gap, may result in an intervening bias on the decision-making process for career developments if, for instance, the demand side would send signals of self-underestimated career chances. There is empirically based evidence that female career chances are assessed less positively by females as opposed to males. Allmedinger and Haarbrücker (2013) used a panel data approach to investigate male and female scripts of life in Germany. The data display some clear gender related divergences with regard to attitudes towards female career chances.

Table 1:

Comparative assessment of the development of female career

\begin{tabular}{lcc}
\hline Assessment & by women & by men \\
\hline improvement & 24.0 & 40.8 \\
same status & 63.8 & 54.7 \\
worsening & 12.2 & 4.5 \\
\hline
\end{tabular}
chances in \% (2012 vs. two years ago)

Source: Allmedinger/Haarbrücker $(2013,56)$. 
Compared to the self-estimation of women (24\%), men reciprocally evaluate the development of career chances of women to have improved to a distinct higher extent (40.8\%). The reverse is true in terms of the statement that female career tracks developed negatively with in the past two years. To a higher percentage, women agreed to this scenario (12.2\%), whereas just about $4.5 \%$ of the interviewed men confirmed this change in female career chances.

Similar findings are suggested by a study that assesses achievement-related self-evaluations in a simulated job interview situation with female participants evaluating their own performance as less successful as compared to their male counterparts: "Compared to the actual performance in the achievement test and to external assessments of the performance in the personal interview, women showed a significant under-evaluation. Males over-evaluated themselves compared to the performance in the written test, but not compared to the external assessments of the personal interview” (Sieverding 2003, 147).

Additionally, women tend to suppress their feelings to a lesser extent than men in interview situations. However, these different traits can result in disadvantages, since emotional suppressors are rated as more competent than emotional non-suppressors (Sieverding 2009).

Even at the other edge of the job hierarchy, i.e. leadership and management, the literature describes the phenomenon of gender differences in self-estimated career expectations. Bosak and Sczesny (2008) state that women tend to express a self-ascribed lack-of-fit to leadership positions as compared to men. Conclusively, women judge themselves as less suitable for a leadership position than men do.

However, based on a decomposition approach, Fietze et al. (2011) argue, that gender differences in personality traits cannot significantly drive gender differences in career opportunities. Their 
findings support the influence of labor market segregation and beliefs in gender related stereotypes in terms of statistical discrimination. In a similar way, Correll $(2001,1691)$ states that “(c)ultural beliefs about gender are argued to bias individuals' perceptions of their competence at various career relevant tasks, controlling for actual ability. To the extent that individuals then act on gender differentiated perceptions when making career decisions, cultural beliefs about gender channel men and women in substantially different career directions”.

Attitudes towards female career opportunities can also be influenced by the level of job satisfaction. However, there is no straight forward relevance, e.g. 'the more satisfied, the more optimistic regarding career opportunities'. Female job satisfaction is also due their family background, since women with children (and presumably comparatively low career aspirations at this phase of life) tend to be significantly happier if they have a job at all compared to working women with no children (Booth, Ours 2008). Hence, a high level of female job satisfaction is not necessarily an indicator for distinct career aspirations with a positive attitude towards female career chances. In fact, the reverse can be true, since, as compared to male workers, a comparatively high female job satisfaction occurs within conservative labor market regimes that come up with restrictions for female career opportunities resulting in the so-called gender-job satisfaction paradox (Kaiser 2007). From this point of view, analyses of female career opportunities should account for the level of female job satisfaction as a control variable.

Based on the above described theoretical is framework the hypothesis could be formulated that female career prospects may turn out to be self-under-estimated and are reciprocally overestimated with regard to the assessment by males, i.e. either colleagues or employers. 
These theoretical implications and its strong empirical evidence coincide with the approach of statistical discrimination. Due to asymmetric information on the labor market to the general disadvantage of employers, average expectations are utilized to compensate the information vacuum within hiring and promotion decisions. The theory of statistical discrimination, as founded by Arrow (1973) and Phelps (1972), has a long tradition in, for instance, explaining wage differentials between male and female workers. Contemporary research on this topic verifies these theoretical assumptions. Belley, Havet and Lacroix (2012) describe differences in male and female wage profiles to be due to differences in mobility and tenure. Their empirical investigation displays men and women having the same wage at the start of their career. Nevertheless, female wages grow to a slower extent as compared to men resulting in a gender wage gap. Within this context, Ejrnæs and Kunze (2013) show the effects of the first childbirth on the wage processes of highly attached women. Each year of leave minimizes the wage by 3 to 5.7 per cent. The wage of mothers who return to the labor market clearly displays the so-called wage penalty for career interruptions. Overall, presumed or actual differences between male and female career profiles result in gender differences in wages that cannot be explained by differences in the educational attainment etc. Based on a decomposition approach, Busch and Holst (2008) detect an unexplained gender wage gap of about 17 percent with respect to full-time employees in Germany for the year 2006. Further studies contain similar hints at the existence of a gender pay gap (cf. Hubler 2005, Brookes et al. 2001 or Black et al. 1999).

Both aspects, a 'female' self-ascribed lag in the self-estimation of career opportunities and the phenomenon of statistical discrimination, may finalise a serious vicious circle. A 'female' selfunder-estimation of career chances may be rated as a proof of the negative assumptions within the frame of statistical discrimination, i.e. an on average expected lower productivity of female as compared to male workers. In this respect, the 'female' self-under-estimation of career 
opportunities ends in a self-fulfilling prophecy towards unneeded female disadvantages on the labor market.

\section{The Gender-Career Estimation Gap in the Public Sector}

The following describes gender differences with regard to self-estimated and reciprocally estimated career expectations of public sector employees in Germany utilizing a public sector dataset. Although there is no direct private sector-comparison feasible with the given data, the focus on public sector employees is of specific interest as one may expect comparatively minor gender differences due to various settings in the German public sector that aim at minimising gender related career discrepancies.

The history of legal approaches to equalizing male and female career chances in the German public sector is long. There are several legal devices in force to promote gender mainstreaming that in particular should enforce equal opportunities on the labor market of the public sector. Each level of the German state, including the European frame, the central state, the federal states and the municipal state, possess their respective legal approaches (cf. Kohler-Gehrig 2009).

Despite these numerous legal opportunities, cross-national comparisons detect an obvious discrepancy in the German public sector with regard to the share of women in public sector leadership positions versus the share of women across the total public sector. Whereas $52 \%$ of public sector workers are female, only $14.5 \%$ of public sector leaders are female. The ratio of the total male share in the public sector against the share of female leadership turns out with 3.31. Other countries do show a much better situation like Canada (45 \% vs. 62 \%), 
Australia (37 \% vs. 57.4 \%), the UK (35 \% vs. 66 \%) or France (21.4 \% vs. 51.7 \%).

Nevertheless, countries like Japan or South Korea end up with even worse results (table 2).

Table 2: Women in the Public Sector

\begin{tabular}{lccc}
\hline Country & Female Leadership (\%) & Total Female Share (\%) & Ratio* \\
\hline Canada & 45.0 & 62.0 & 0.84 \\
UK & 35.0 & 66.0 & 0.97 \\
South Africa & 33.0 & 65.2 & 1.05 \\
Australia & 37.0 & 57.4 & 1.15 \\
Italy & 27.0 & 64.7 & 1.31 \\
United States & 31.0 & 57.0 & 1.39 \\
Brazil & 32.1 & 47.6 & 1.63 \\
Russia & 13.0 & 71.0 & 2.23 \\
France & 21.4 & 51.7 & 2.26 \\
Argentina & 19.0 & 56.0 & 2.32 \\
Germany & 14.5 & 52.0 & 3.31 \\
Mexico & 14.0 & 45.5 & 3.89 \\
China & 11.5 & 42.5 & 5.00 \\
Turkey & 13.6 & 23.0 & 5.66 \\
South Korea & 8.6 & 42.0 & 6.74 \\
Indonesia & 8.7 & 20.0 & 9.20 \\
India & 7.7 & 19.0 & 10.52 \\
Japan & 2.5 & 42.0 & 23.20 \\
\hline Source: Schreiber $(2013)$, author's calculations, * total male $\%$ &
\end{tabular}

Source: Schreiber (2013), author's calculations, * = total male \% / female leadership \%

As to why do these differences occur? The German public sector is characterized by comparatively strict career settings in terms of achieving a leadership position. Specific tenure restrictions have to be met or occupational requirements are important to fill a leadership position, e.g. the occupation of a judge. Nevertheless, for German women, the public sector is attractive to put a work-family life balance into practise as mirrored by the high share of female workers in this sector. However, as the German private sector labor market is still comparatively conservative with regard to a work-family life balance, the low share of female leadership positions could also be due to a selection process with female public workers entering this section with no leadership position aspirations but the aim to combine family life and work. In other countries, a higher share of female leadership position could be due to the 
comparatively non-formal career steps with less restrictions like occupational requirements (Australia, Canada, UK, US). In contrast, India and Japan still stick to traditional versions of gender roles.

\section{The Data}

The data used in the current study, the so-called 'PSJS-data' (Public Sector Job Satisfaction Data), were collected by the author and arise from a case study of a communal public administration. The cross-sectional data were gathered in 2011 in a medium-sized city with some 60.000 inhabitants in the German county North-Rhine Westphalia. In order to gain a high response rate, paper and pencil-questionnaires were handed over to the entire population of public employees $(\mathrm{N}=874)$.

Fortunately, with $57 \%$, the overall response rate was comparatively high $(\mathrm{n}=498)$. The total sample of 498 respondents includes a sub-sample of cleaning workers $(n=81)$. The particularity of this sub-sample is a lean sub-questionnaire that refers to a fewer number of questions and the choice between different languages (German or Turkish). Due to the two different versions of the questionnaires, long vs. lean, the sampled data refer either to $n=498$ or $n=417$ accounting for a questionnaire version with and a version without cleaning worker respondents. The descriptive and regression analyses as presented here will account for the sample where the cleaning workers are excluded, since information on career prospects was not gathered for cleaning workers.

In order to raise information with regard to potential gender related differences in self-and reciprocally estimated career expectations, the questionnaire of the above described data set contains several items for different career aspects (chart 1). 
Chart 1: Questionnaire Items for the Topic of Estimated Career Expectations

1. Please give an assessment of male career chances regarding
a) education/training
good bad don't know
b) further education/training
c) upward career mobility
d) leadership position

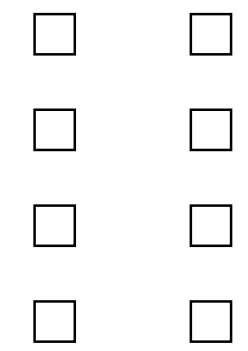

2. Please give an assessment of female career chances regarding
a) education/training
good bad don't know
b) further education/training
c) upward career mobility
d) leadership position

Firstly, the survey participants were asked to gauge the career in terms of education and training as such. Hence, this question aims at an estimation of the chances to be accepted for an apprenticeship, for example. Secondly, the questionnaire considers 'further education and training', i.e. to evaluate the chances of enhancing the level of qualification by the attendance of respective courses, like training on the job-courses. A third item is related to career opportunities. Here survey participants should estimate the chances to experience an upward mobility in terms of career opportunities. The fourth item asks for an estimation of the chances to attain a leadership position. All items had to be answered with either 'good', 'bad' or 'don't know'. Hence, the focus, as set in this analysis, is restricted to male and female career opportunities, i.e. male and female public workers state a self-estimation and a respective reciprocal evaluation of the careers prospects of the their male or female colleagues. Hence the estimation contains both, a forecast and a comparison likewise. 


\section{Empirical Findings}

At first sight for the analysis of male career opportunities, it becomes obvious that with shares between $38 \%$ and $50 \%$, the categories 'good' and 'don't know' attain comparatively high values. Hence, a high proportion of male and female public workers cannot evaluate career chances of male workers due to a restricted basis of knowledge. On the other hand, only a comparatively low proportion gauge career opportunities of male colleagues as 'bad' (chart 2). Some seventeen percent of the respondents have chosen this category for career upward mobility and about $15 \%$ in terms of leadership whereas only $11 \%$ regard this estimation for further education and training and only about $7 \%$ for education and training.

Chart 2: Career-Prospect Estimation for Male Employees (in \%)

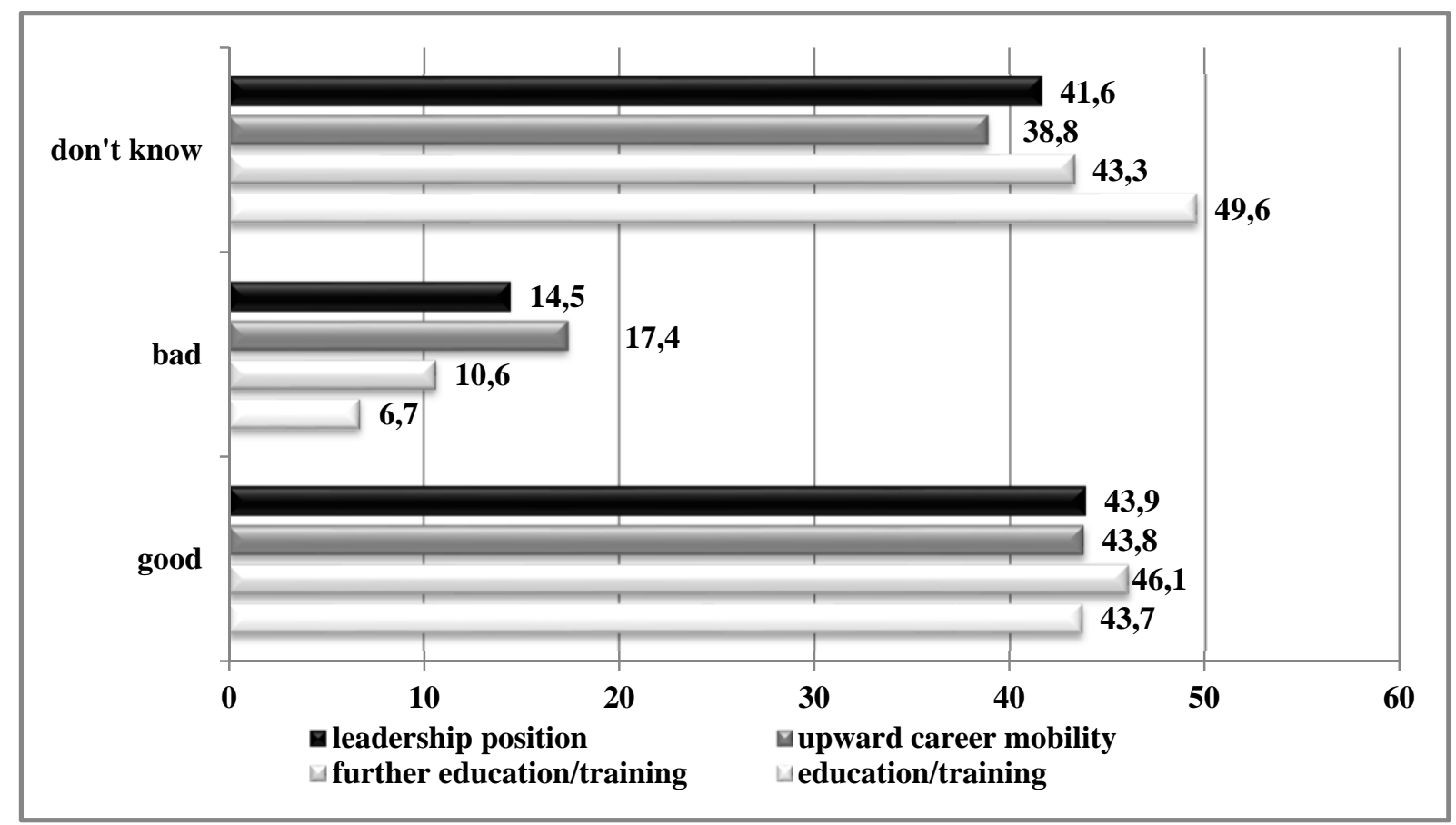

Source: author's calculations.

However, if the results for the estimation of male career prospects are analysed separately based on the vote of male and female public employees, a clear divergence becomes obvious. Females 
evaluate the chances of their male colleagues far better than males their own opportunities (cf. chart 2.1 versus chart 2.2).

The gender differences concerning these separate assessments are statistically significant for each category (cf. tables A-1 to A-4, placed in the annex of this paper). Hence, the findings support the tendency towards a reciprocal overestimation of male career prospects by females and a self-under-estimation of male career chances by males. The higher the career level, ranked from education and training towards upward career mobility and leadership position, the more obvious the self-under-estimation of male employees.

Chart 2.1: Career-Prospect Estimation for Male Employees by Female Employees (in \%)

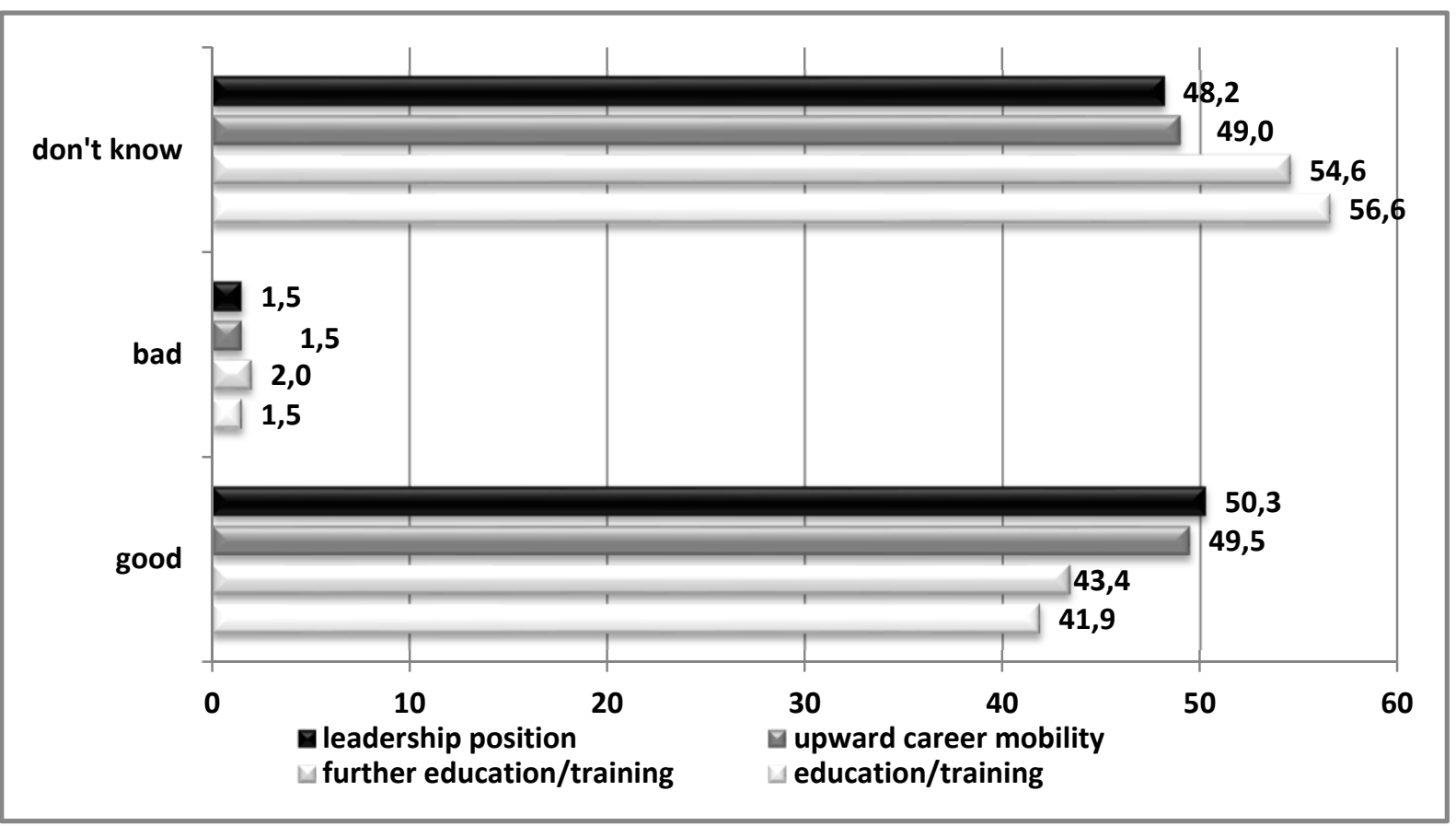

Source: author's calculations. 
Chart 2.2: Career-Prospect Estimation for Male Employees by Male Employees (in \%)

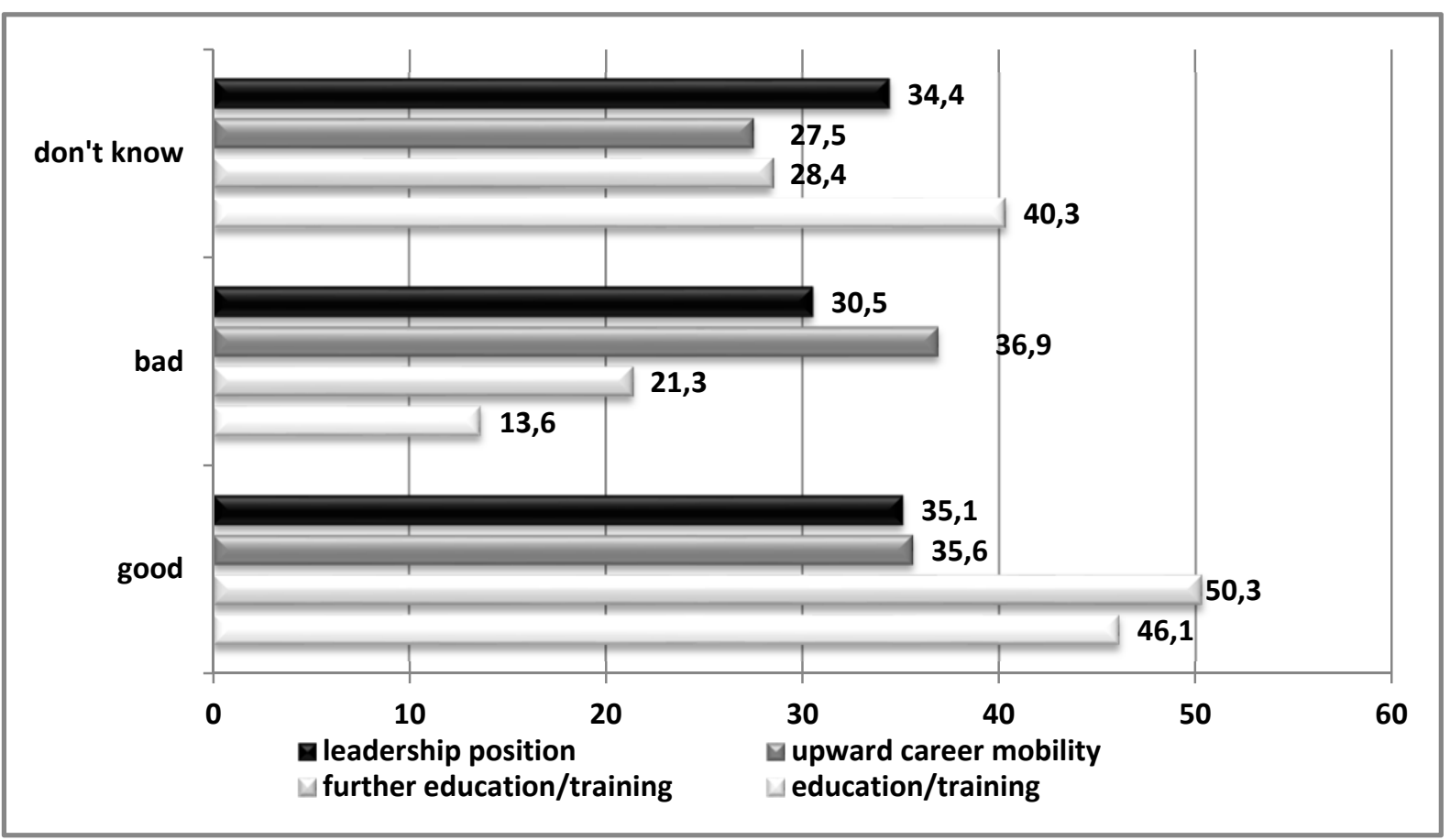

Source: author's calculations.

Similarly, the initial analysis of female career prospects shows a high share of respondents who are not able to assess female career opportunities. Additionally, the option to experience upward career mobility and the chance to attain a leadership position are estimated as bad to a comparatively high share (26.2 \% and $24.6 \%$, respectively).

A separate calculation of career prospects by female and male respondents shows again a more optimistic reciprocal assessment by male public employees as compared to the more pessimistic self-evaluation by female public employees. This becomes particularly true for the categories ‘upward career mobility’ and ‘leadership position’ (cf. chart 3.1 versus chart 3.2). Females gauge their chances for an upward career mobility to $34.3 \%$ and with regard to attaining a leadership position to $31.1 \%$ as bad, whereas their male counterparts assess females chances in these categories to a significantly lower share as bad (13.0 \% and $14.5 \%$ respectively). 
Chart 3: Career-Prospect Estimation for Female Public Workers (in \%)

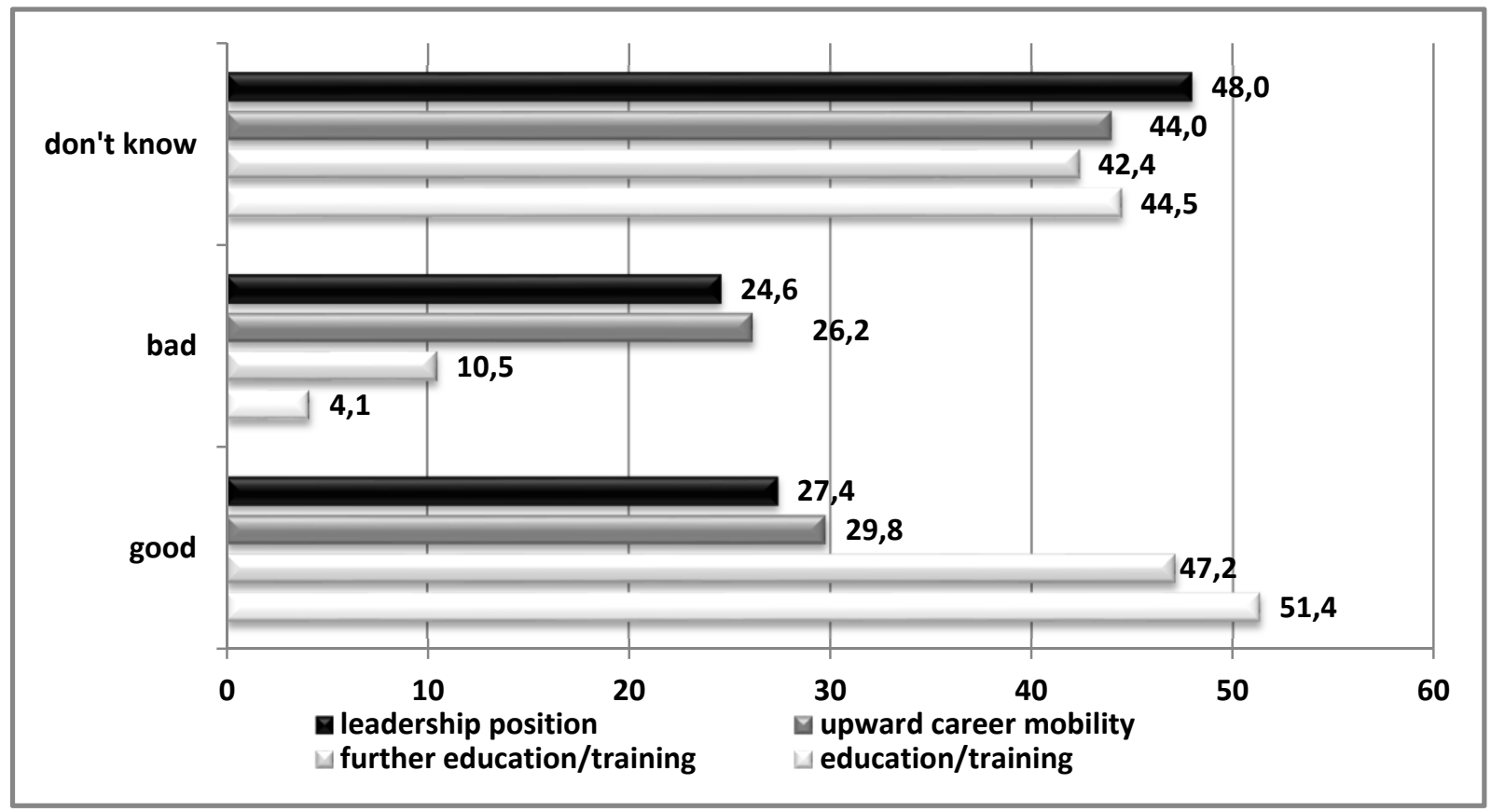

Source: author's calculations.

Chart 3.1: Career-Prospect Estimation for Female Employees by Female Employees (in \%)

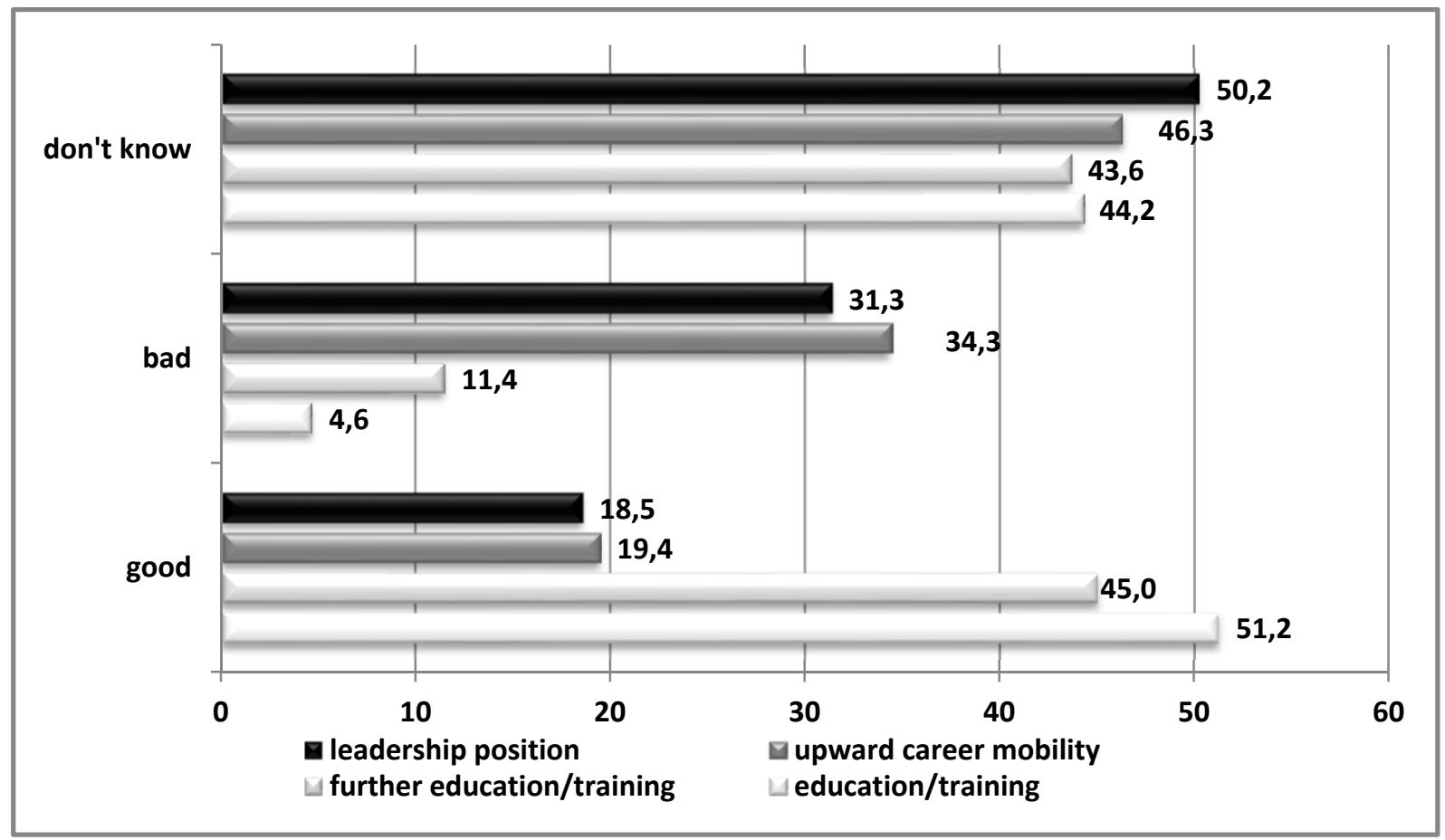

Source: author's calculations. 
Chart 3.2: Career-Prospect Estimation for Female Employees by Male Employees (in \%)

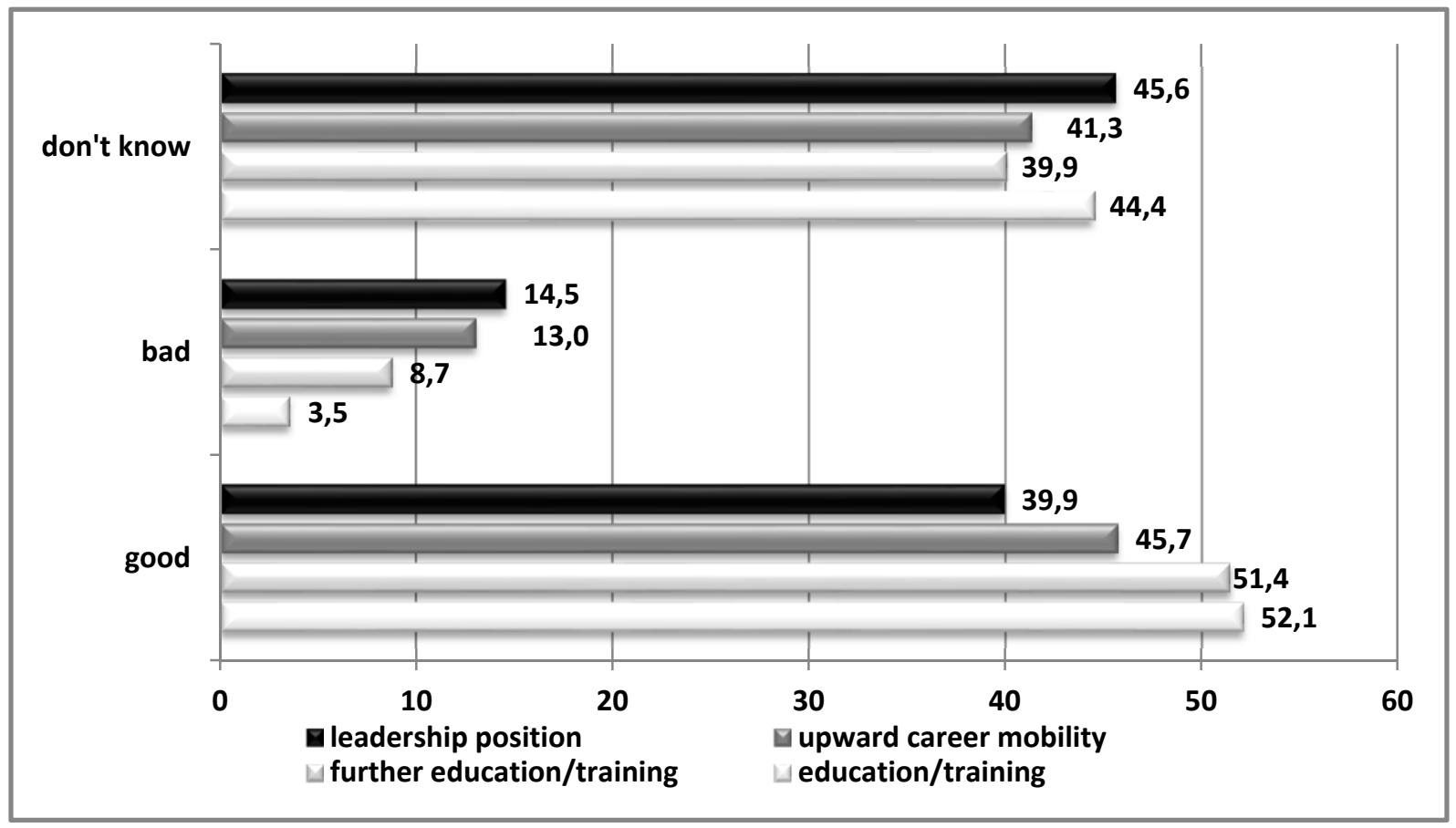

Source: author's calculations.

The analyses show the tendency that career prospects of the respective opposite sex are evaluated in a more positive way as opposed to the career chances of the own sex. This is true for career paths of both, men and women. For the latter, the descriptive results turn out to be statistically significant for upward career mobility and leadership position only (cf. tables A-5 to A-8). This finding coincides with the rising magnitude of gender differences if the career ladder is climbed, i.e. if the level of career becomes higher with the lowest level set as 'education and training’ and the highest level defined as ‘leadership position’.

Descriptive differences in the self-estimation and reciprocal estimation of male career tracks display a less pessimistic assessment of male career chances by females compared to the selfestimation by male public employees (chart 4). However, female employees state to a higher 
extent to be unable to evaluate male career prospects. However, the lowest percentage in this case is displayed for the category 'leadership position'.

Chart 4: Gender Differences in Career-Prospect Estimation for Male Employees (Difference in percentage points, female versus male employees)

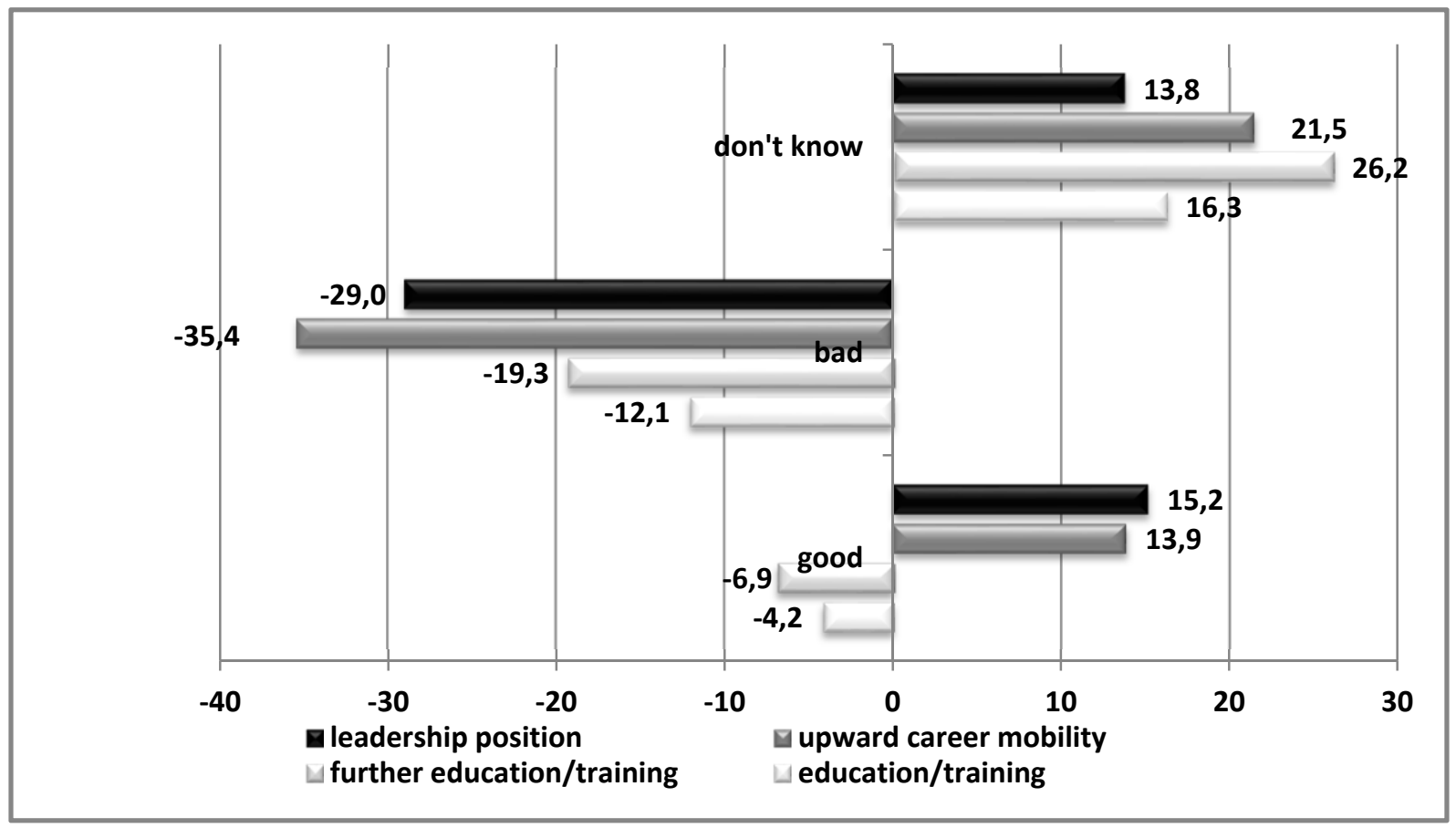

Source: author's calculations.

Chart 5 summarizes the overall descriptive differences in gender related discrepancies of assessing prospective female career profiles. Hence, women possess a less positive selfestimation when gauging their own career chances as opposed to the reciprocal estimation of female career chances by their male counterparts. In particular, the discrepancies emerge when the aspects upward career mobility and leadership positions are evaluated. Here, the gendercareer estimation gap clearly emerges. 


\section{Chart 5: Gender Differences in Career-Prospect Estimation for Female Employees}

(Difference in percentage points, female versus male employees)

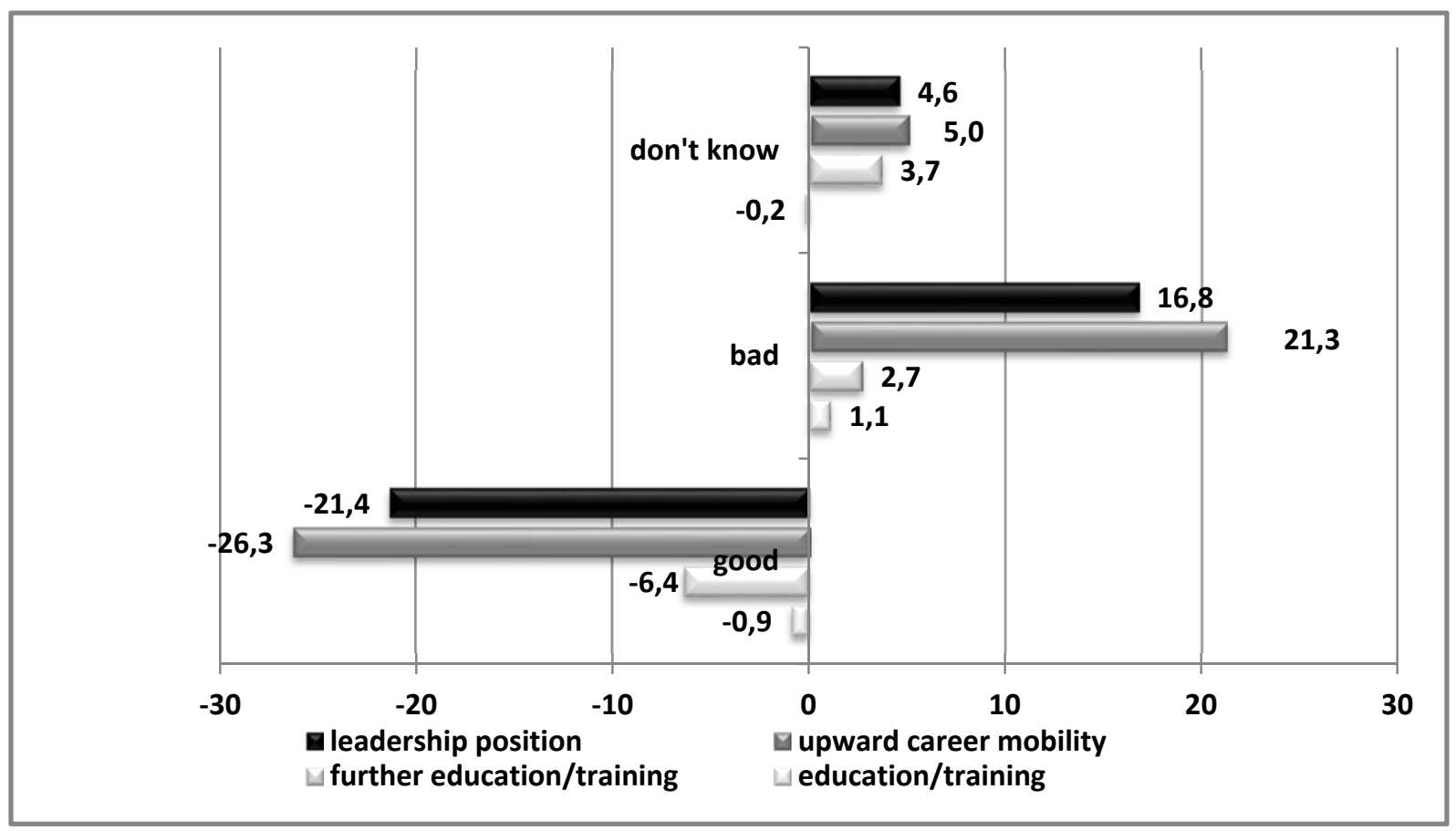

Source: author's calculations.

However, comparing chart 4 versus chart 5, it becomes obvious that gender related differences in self- and reciprocal estimation of career opportunities is most pronounced with regard to female career chances. From this point of view, a specific imbalance can be identified within the gender-career estimation gap.

Based on the theoretical implications as discussed in section 3, cognitive gender differences (e.g. regarding educational attainment) and/or non-cognitive gender differences (e.g. in terms of socialisation) between male and female workers may drive the displayed distinct gender differences in the evaluation of female career chances.

In a first stance of detecting reasons behind this gender differences in assessing the female career prospects, differences in the educational attainment are 'historical' in developed 
countries. In former generations, women clearly were disadvantaged due to lower educational levels. However, today, statistics show higher educational achievements for women as compared to men both in terms of school certificates and tertiary education in Germany and other central European countries (OECD 2012).

With regard to non-cognitive aspects, there are manifold aspects with differences between men and women that may drive the above described results. In terms of preferences, women tend to be more risk-averse than men (Croson, Gneezy 2009; Charness, Gneezy, 2011) that entail no or at least less overestimation of one’s own capabilities (Barber, Odean 2001). Hence, female workers evaluate their own career opportunities in a more cautious rather than in an offensive way like their male counterparts. Accordingly, female workers tend towards a self-under-estimation of their own career prospects and a reciprocal over-estimation of male career options.

With the focus put on competitiveness, women may find themselves in a more defensive position, in particular in competitive situations against male applicants for a job or regarding a promotion opportunity (Niederle, Westerlund 2007; Gneezy et al. 2013). These addressed gender differences are likely to have an impact on gender differences in the evaluation of male and female career prospects resulting in different labor market statuses.

However, a direct impact of non-cognitive gender differences on wage differentials as causation for wage discrimination is not verified so far (Fortin 2008; Manning, Swaffied, 2008). In contrast, male and female workers display the same likelihood to negotiate wages if wages are explicitly announced to be negotiable. However, if no information is given with regard to wage negotiations, male applicants initiate wage negotiations to a higher extent as 
compared to female applicants (Leibbrandt, List 2012). Hence, labor market statuses, wage differentials and wage discrimination might be due to these specific gender differences in negotiation affinities (Babcock, Laschever 2003).

\section{Regression Approach}

In order to gain a more detailed insight into the determination of the gender-career estimation gap a mulitnominal logit model (m-logit) is utilized in order to account for various information that is available in the data. ${ }^{3}$ The model is applied to male and female career expectations respectively.

The data were pooled for the regression approach to end up with sufficient number of observations. The pooling strategy appends cross-sectional data in a fourfold way with regard to respective career categories (education/training, further education and training, upward career mobility and leadership position). Thereafter, the m-logit accounts for the repeated observation of identical individuals by means of a Huber-White estimator (cf. Huber 1967 and White 1980; 1982).

Table 3 describes the exogenous variables of the m-logit. The dependent variable is again the assessment of male or female career opportunities rated between 'good' (coded as ' 1 '), 'bad' (coded as '2') or 'don't know' (coded as '3').

Similarly to the broad descriptive analyses the m-logit is related to both sexes, but is accounting to control for sex in order to test for potential gender effects. Moreover, further individual characteristics are included in the model that potentially could have an effect on the evaluation of career prospects, like age, job status (tenured civil servant versus no tenured civil servant status, part-time, type of contract), tenure, job satisfaction, satisfaction with staff

\footnotetext{
${ }^{3}$ A detailed description of the m-logit is offered by Long 1997, 148 et sqq.
} 
council, attitude towards the public service as such (necessity for modernisation). Additionally, the model differentiates if career prospects are assessed from a leadership position's point of view or not. This is especially important as a leadership position is related to decide upon hiring and promoting employees. Strong beliefs and/or valid knowledge in terms of male or female career opportunities may have an impact on decisions regarding hiring- and promotion processes. Here, the demand-side, i.e. the evaluation of employee's potentials with regard to the career development (job applicants or resident workers) by employers plays an important role.

Table 3: Variables Measuring Respondent's Characteristics (M-Logit Model)

\begin{tabular}{l|l|l}
\hline Variable & Description & Coding \\
\hline Sex & sex of the respondent & $0=$ female, $1=$ male \\
Leadership & $\begin{array}{l}\text { leadership position } \\
\text { tenured civil servant status } \\
\text { Tenured civil servant }\end{array}$ & $\begin{array}{l}0=\text { no, } 1=\text { yes } \\
\text { tenure in years }\end{array}$ \\
Tenure & up to 24 years of age & decimal or full years \\
Age24 & 25 to 34 years of age & $0=$ no, $1=$ yes \\
Age25-34 & 35 to 44 years of age & $0=$ no, $1=$ yes \\
Age35-44 & 45 to 54 years of age & $0=$ no, $1=$ yes \\
Age45-54 (reference category) & $55+$ years of age & $0=$ no, $1=$ yes \\
Age55+ & working on a part-time basis & $0=$ no, $1=$ yes \\
Part-time job & possessing a temporary contract \\
Temporary contract & level of job satisfaction $1=$ yes \\
Job-satisfaction & necessity: admin. modernisation $1=$ yes \\
Administration modernisation & dissatisfaction with staff council & $0=$ not at all, ..., $10=$ totally \\
Dissatisfaction staff council & &
\end{tabular}

Source: author's compilation.

Placed in the annex of the paper, table A-9 exhibits the descriptive setting of the variables in the first m-logit that accounts for the assessment of male career prospects. About $42.5 \%$ of the observations are due to male respondents, i.e. female employees are in the majority in this sample. Leadership positions are represented to some $2.2 \%$ and the status of a tenured civil servant is relevant for about $50 \%$ of the regression population. With about $37 \%$, the age group of 45 to 54 years of age constitutes the most frequent age group. About a quarter of the 
respondents are working on a part-time basis and some $13 \%$ possess a temporary contract. Their job satisfaction averages out at 6.8 using the ordinary scale measuring job satisfaction between 0 (not satisfied at all) and 10 (totally satisfied). About $44 \%$ of the respondents would appreciate modernisation processes within the administration and some $30 \%$ are dissatisfied with their staff council.

Controlling for other implemented effects, the results of the m-logit (cf. table A-11) display again a pessimistic self-estimation of male career prospects as opposed to the reciprocal estimation of male career chances by female employees. The marginal effect for the variable 'sex' (coded with ' 1 ' for male and ' 0 ' for female') turns out to be highly significant to judge male career prospects as comparatively 'bad'. Hence, men tend to assess their own career prospects even worse than women reciprocally estimate the career chances of their male counterparts. This finding related to the variable 'sex' of table A-11 coincides with the findings of table A-12 ${ }^{4}$ : Male employees reciprocally estimate career prospects of their female colleagues less pessimistic and more optimistic than women self-estimate their own career opportunities. Accordingly, the gender-career estimation gap is clearly validated by the regressions.

If the respondents evaluate male and female career opportunities from the point of holding a leadership position, the tendency emerges to state that career opportunities are 'good', both for male and female employees. This result could be interpreted as a general statement of loyalty from the perspective of a leadership position. For instance, the coding of the leadership position assigns the governing and deputy mayor and their office staff to this position. Since these positions are elected by the majority of the voters in communal elections, the attitude towards career prospects of their subordinated employees is stated to be

\footnotetext{
${ }^{4}$ The descriptive results for table A-12 are displayed by table A-10.
} 
positive. This may be interpreted as a device to maximize votes within the meaning of a 'political message' sent to their potential voters. ${ }^{5}$

On a high significant level, civil servants judge male career prospects as 'good' (table A-11) whereas civil servants tend to estimate female career chances as 'bad' (table A-12). The interpretation of these results is consistent with the above described outcomes, since female are overrepresented within the population of civil servants in the samples (54\% and $57 \%$ ). To a higher extent, with rising tenure, male and female career prospects are positively evaluated as 'good'. This finding could be due to the own experience of promotion and career development, since in the German administrative sector, promotion processes are mainly due to automatic promotions with rising age. Similar significant marginal effects emerge for male and female career opportunities with regard to the age-bands. However, for female career options, those who are 55 years of age and older, tend to assess female career developments to be 'bad'. Again this finding may be due to own experiences within this generation. Holding a part-time job clearly hinders the respondents to deliver a 'good' or 'bad'judgement, as the marginal effects show up to be positive regarding the category 'don't know'. This is particularly true for the assessment of female career chances. The result mirrors the position of these respondents, as part-timers are not being fully integrated in the workplace of the public administration. This kind of indecision is potentially due to family duties that currently form careers aspirations as being indifferent and/or undefined as opposed to those employees who are working on a full-times basis. The finding becomes even more conclusive, as a separate descriptive analysis of part-timers in the m-logit sample crosstabulated with the variable 'sex' shows that about $93 \%$ of the part-timers are female employees. Working on a basis of a temporary contract has virtually no impact on the

\footnotetext{
${ }^{5}$ The interpretation is related to the so-called Economic Theory of Democracy (cf. Downs 1957).
} 
judgement of career prospects of male and female employees, as temporary contracts are not very common in the German public administration.

In contrast, with rising job satisfaction, the respondents explicitly evaluate career opportunities in an optimistic rather than in a pessimistic way. Furthermore, the attitude of appreciating modernisation with the public administration has no impact, whereas dissatisfaction with the work council yields to an assessment of female career prospects to develop in a bad way (cf. table A-12). The latter finding clearly addresses the work council to be responsible for equalizing career profiles of men and women.

\section{Conclusions}

The descriptive and regression analyses clearly display a pessimistic self-under-estimation of female career prospects as opposed to the reciprocal over-estimation of male career chances by female employees in the case study of the German public sector. Similar is true in respect to the self- and reciprocal evaluation of male career prospects of male employees. Accordingly, a gender-career estimation gap clearly occurs. Female (male) employees tend to under-estimate (over-estimate) female career chances. The 'objective truth' of 'real career development potentials' is placed somewhere in between these instances of under- and over-estimation of career prospects. However, these 'real career chances' are more or less only solely feasible, if no gender-career estimation gap would be in force. Hence, as soon as a gender-career estimation gap occurs, career potentials are utilized in a suboptimal way. In particular with regard to female career potentials on the labor market, their human and social capital would partially be wasted.

The combination of a gender-career estimation gap and statistical discrimination to the disadvantage of female employees tend to augment the level of overall female discrimination in 
the labor market resulting in respective negative consequences with regard to the well-being of working women. In contrast, male workers experience an under-estimation of their career chances as well but will additionally not have to face statistical discrimination that is due to an average expectance of a low productivity in the labor market, e.g. in terms of presumed interrupted career profile due to family responsibilities.

From this point of view, the formation of decisions with regard to practical career developments during hiring and promotion processes, will be influenced by 'beliefs' and 'power' in respect to male and female career chances. The power of utilizing beliefs is partially incumbent on the owner of a leadership position in the private or public sector of the labor market. At this stance biased self- and reciprocal career estimations are likely to possess an impact on the formation of decisions with regard to practical career developments. It is the mechanism of a reciprocal determinism that may act as a verification of a seemingly lower productivity of female workers within the meaning of statistical discrimination. The mechanism of statistical discrimination is extensively described in the literature as a widely existent failure when it comes to decide upon a selection of human resources. Goldin and Rouse (2000) for instance show that far more female musicians are engaged in an orchestra if the application procedure is organized in a blind approach, i.e. the jury is allowed to hear but not to see the musicians.

However, the regression results suggest that those who decide upon career developments, i.e. public employers or employees possessing a leadership position, state that career prospects of their male and female employees are 'good'. Additionally, decisions on recruitment and promotion are always not entirely due to a 'single decider'. In particular, the (German) public sector offers various institutions that participate in the processes of deciding upon hiring and promoting like staff councils, unions or equal opportunity commissioners. Additionally, an equal 
proportion of males and females delegated to these institutions will be a very important requirement to deliver the respective decisions for equal opportunities because self- and reciprocal 'beliefs' in male and female career opportunities, potentially set in a converse manner against each other, are likely to be equalized by proportionality. An implementation and involvement of women's quota in the labor market might also flank equal opportunities. However, this approach may not be the optimal remedy against converse beliefs in male and female career opportunities. On the contrary, the gender-career estimation gap might even be fostered by means the 'artificial character' women’s quota in the labor market, since this device may possess a 'lack in the depth of focus' and therefore may not reach insistent beliefs in male and female career chances.

In contrast, anonymous applications are a good example for a device of how to absorb the vicious circle of statistical discrimination and converse beliefs in female and male career chances. For instance the Belgium public sector is successfully hiring its employees since 2005 on the bases of anonymous application schemes. Similar challenging results in terms of this approach are described by Krause et al. (2012). The authors also hint at some drawbacks of anonymous applications. However, anonymous applications may be more suitable for the public sector in general since the public sector of the labor market traditionally provides (more) devices to attain equal opportunities as opposed to the private sector.

Additionally, supporting female career developments ‘on the job’ may be an important approach to smoothen the magnitude of the self-under estimation of career opportunities and a selfascribed lack-of-fit to leadership positions. This empowerment strategy could be implemented by general and/or pay negotiation training courses (cf. Booth 2007). 


\section{Further Research}

There are different strands of research that could be accelerated in order to boost the knowledge within the field of the gender-career estimation gap. Accordingly, various research approaches might be fruitful to make progress with regard to causes and consequences of gender differences in the self- and reciprocal estimation of career opportunities. This includes research regarding remedies against the respective negative consequences of these beliefs in male and female career chances.

\section{Causes}

To a higher extent, the mechanism of building-up gender related differences in self- and reciprocal beliefs in career chances should be investigated. By means of personal interviews or lab experiments, qualitative research could shed some more light on the basics of self- and reciprocal beliefs in career opportunities. This explorative perspective is very important to understand the reasons in a better way as to why the gap between male and female self- and reciprocal emerges. This research approach should also include the investigation of beliefs in male in female career chances that may still be fostered by the demand side of labor markets, i.e. employers. Qualitative expert interviews with employers and their institutional representatives may be devices to implement this research approach. If the background of these beliefs are detected, quantitative research should be utilized in order to display the overall empirical magnitude, i.e. to quantify the distribution of these beliefs within the population.

\section{Consequences and Remedies}

Having identified mechanisms and actors of the gender-career estimation gap, we are interested in its and their consequences respectively. For instance, cognitive and non-cognitive differences 
between men and women as discussed by Bertrand (2010) might be relevant for labor market related consequences within the field of statistical discrimination. The gender pay gap is a prominent consequence that occurs within the field of statistical discrimination. However, this phenomenon needs more validation in order to understand the steps that are made from step one (beliefs in differences) towards step 2 (reactions based on beliefs). From this point of view, the aspect of reciprocal determinism should be integrated in research activities to a higher extent in order to understand the interaction between signals sent by (male and) female employees, like an average self-under-estimation of career chances and the utilization of these signals by employers within the process of screening job- and/or promotion applicants.

The phenomenon of statistical discrimination is well known and labor market actors as well as politics have developed programs in order to absorb this disturbing aspect. However, the effectiveness and efficiency of these programs, like a women's quota in the labor market or anonymous applications, have not yet been consequently evaluated. A valuable field of further research would be the empirical identification of differences between the public and private sector of the economy. This kind of comparison could deliver more detailed information on the question, if a higher extent of (legal) interventions as realized in the public sector with regard to equalizing career opportunities also leads to a comparatively higher extent of smoothening labor market discrimination. As a starting point, the paper at least delivers the finding that the public sector as such possesses a distinct gender-career estimation gap that accelerates labor market discrimination to the disadvantage of the female workforce. 


\section{Annex}

Table A-1: Gender Differences in the Estimation of Male Career Prospects (Education and Training) in \% (cases in parentheses)

\begin{tabular}{l|cc|cc|cc} 
& \multicolumn{2}{|c|}{ Females } & \multicolumn{2}{c|}{ Males } & \multicolumn{2}{c}{ total } \\
\hline Good & 41.9 & $(85)$ & 46.1 & $(71)$ & 43.7 & $(156)$ \\
\hline Bad & 1.5 & $(3)$ & 13.6 & $(21)$ & 6.7 & $(24)$ \\
\hline Don't know & 56.6 & $(115)$ & 40.3 & $(62)$ & 49.6 & $(177)$ \\
\hline total & 203 & & \multicolumn{2}{|c|}{154} & \multicolumn{2}{|c}{357}
\end{tabular}

Pearson $\operatorname{chi}^{2}(2)=24.3599 \operatorname{Pr}=0.000$

Source: author's calculations.

Table A-2: Gender Differences in the Estimation of Male Career Prospects (Further Education and Training) in \% (cases in parentheses)

\begin{tabular}{l|cc|cc|cc} 
& \multicolumn{2}{|c|}{ Females } & \multicolumn{2}{c|}{ Males } & \multicolumn{2}{c}{ total } \\
\hline Good & 42.7 & $(87)$ & 50.3 & $(78)$ & 46.1 & $(165)$ \\
\hline Bad & 2.5 & $(5)$ & 21.3 & $(33)$ & 10.6 & $(38)$ \\
\hline Don't know & 54.7 & $(111)$ & 28.4 & $(44)$ & 43.3 & $(155)$ \\
\hline total & 203 & \multicolumn{2}{|c|}{155} & \multicolumn{2}{|c|}{358}
\end{tabular}

Pearson $\mathrm{chi}^{2}(2)=44.4470 \operatorname{Pr}=0.000$

Source: author's calculations. 
Table A-3: Gender Differences in the Estimation of Male Career Prospects (Upward Career Mobility) in \% (cases in parentheses)

\begin{tabular}{l|cc|cc|cc} 
& \multicolumn{2}{|c|}{ Females } & \multicolumn{2}{c|}{ Males } & \multicolumn{2}{|c}{ total } \\
\hline Good & 50.2 & $(102)$ & 35.6 & $(57)$ & 43.8 & $(159)$ \\
\hline Bad & 2.0 & $(4)$ & 36.9 & $(59)$ & 17.4 & $(63)$ \\
\hline Don't know & 47.8 & $(97)$ & 27.5 & $(44)$ & 38.8 & $(141)$ \\
\hline Total & 203 & \multicolumn{2}{|c|}{160} & \multicolumn{2}{|c}{363}
\end{tabular}

Pearson $\mathrm{chi}^{2}(2)=76.6557 \operatorname{Pr}=0.000$

Source: author's calculations.

Table A-4: Gender Differences in the Estimation of Male Career Prospects (Leadership Positions) in \% (cases in parentheses)

\begin{tabular}{l|cc|cc|cc} 
& \multicolumn{2}{|c|}{ Females } & \multicolumn{2}{c|}{ Males } & \multicolumn{2}{c}{ total } \\
\hline Good & 50.5 & $(102)$ & 35.1 & $(53)$ & 43.9 & $(155)$ \\
\hline Bad & 2.5 & $(5)$ & 30.5 & $(46)$ & 14.5 & $(51)$ \\
\hline Don't know & 47.0 & $(95)$ & 34.4 & $(52)$ & 41.6 & $(147)$ \\
\hline total & 202 & & \multicolumn{2}{|c|}{151} & \multicolumn{2}{|c}{353}
\end{tabular}

Pearson $\mathrm{chi}^{2}(2)=54.8050 \operatorname{Pr}=0.000$

Source: author's calculations. 
Table A-5: Gender Differences in the Estimation of Female Career Prospects (Education and Training) in \% (cases in parentheses)

\begin{tabular}{l|cc|cc|cc} 
& \multicolumn{2}{|c|}{ Females } & \multicolumn{2}{c|}{ Males } & \multicolumn{2}{c}{ total } \\
\hline Good & 50.9 & $(112)$ & 52.1 & $(74)$ & 51.4 & $(186)$ \\
\hline Bad & 4.6 & $(10)$ & 3.5 & $(5)$ & 4.1 & $(15)$ \\
\hline Don't know & 44.5 & $(98)$ & 44.4 & $(63)$ & 44.5 & $(161)$ \\
\hline total & 220 & \multicolumn{2}{|c|}{142} & \multicolumn{2}{|c}{362}
\end{tabular}

Pearson $\mathrm{chi}^{2}(2)=0.2435 \operatorname{Pr}=0.885$

Source: author's calculations.

Table A-6: Gender Differences in the Estimation of Female Career Prospects (Further Education and Training) in \% (cases in parentheses)

\begin{tabular}{l|cc|cc|cc} 
& \multicolumn{2}{|c|}{ Females } & \multicolumn{2}{c|}{ Males } & \multicolumn{2}{c}{ total } \\
\hline Good & 44.4 & $(96)$ & 51.4 & $(71)$ & 47.2 & $(167)$ \\
\hline Bad & 11.6 & $(25)$ & 8.7 & $(12)$ & 10.4 & $(37)$ \\
\hline Don't know & 44.0 & $(95)$ & 39.9 & $(55)$ & 42.4 & $(150)$ \\
\hline total & 216 & & \multicolumn{2}{|c|}{138} & \multicolumn{2}{|c}{354}
\end{tabular}

Pearson $\operatorname{chi}^{2}(2)=1.8817 \operatorname{Pr}=0.390$

Source: author's calculations. 
Table A-7: Gender Differences in the Estimation of Female Career Prospects (Upward Career Mobility) in \% (cases in parentheses)

\begin{tabular}{l|cc|cc|cc} 
& \multicolumn{2}{|c|}{ Females } & \multicolumn{2}{c|}{ Males } & \multicolumn{2}{c}{ total } \\
\hline Good & 19.9 & $(44)$ & 45.7 & $(63)$ & 29.8 & $(107)$ \\
\hline Bad & 34.4 & $(76)$ & 13.0 & $(18)$ & 26.2 & $(94)$ \\
\hline Don't know & 45.7 & $(101)$ & 41.3 & $(57)$ & 44.0 & $(158)$ \\
\hline Total & 221 & \multicolumn{2}{|c|}{138} & \multicolumn{2}{|c}{359}
\end{tabular}

Pearson $\operatorname{chi}^{2}(2)=34.0446 \operatorname{Pr}=0.000$

Source: author's calculations.

Table A-8: Gender Differences in the Estimation of Female Career Prospects (Leadership Positions) in \% (cases in parentheses)

\begin{tabular}{l|cc|cc|cc} 
& \multicolumn{2}{|c|}{ Females } & \multicolumn{2}{c|}{ Males } & \multicolumn{2}{c}{ total } \\
\hline Good & 19.5 & $(42)$ & 39.9 & $(55)$ & 27.4 & $(97)$ \\
\hline Bad & 31.0 & $(67)$ & 14.5 & $(20)$ & 24.6 & $(87)$ \\
\hline Don't know & 49.5 & $(107)$ & 45.6 & $(63)$ & 48.0 & $(170)$ \\
\hline total & 216 & \multicolumn{2}{|c|}{138} & \multicolumn{2}{|c}{354}
\end{tabular}

Pearson $\mathrm{chi}^{2}(2)=22.4235 \operatorname{Pr}=0.000$

Source: author's calculations. 
Table A-9: Descriptives, M-Logit Model (Male Career Prospects)

\begin{tabular}{l|lc|lll}
\hline Variable & Obs & Mean & Std. Dev. & Min & Max \\
\hline Assessment male career prospects & 1303 & 1.9916 & 0.9426 & 1 & 3 \\
\hline Sex & 1303 & 0.4252 & 0.4956 & 1 & 3 \\
Leadership & 1303 & 0.2150 & 0.1451 & 0 & 1 \\
Civil servant & 1303 & 0.5035 & 0.5001 & 0 & 1 \\
Tenure & 1303 & 16.3092 & 10.7667 & 0.166 & 47 \\
Age24 & 1303 & 0.0338 & 0.1807 & 0 & 1 \\
Age25-34 & 1303 & 0.1819 & 0.3859 & 0 & 1 \\
Age35-44 & 1303 & 0.2748 & 0.4466 & 0 & 1 \\
Age45-54 & 1303 & 0.3707 & 0.4832 & 0 & 1 \\
Age55+ & 1303 & 0.1328 & 0.3395 & 0 & 1 \\
Part-time job & 1303 & 0.2740 & 0.4462 & 0 & 1 \\
Temporary contract & 1303 & 0.1305 & 0.3369 & 0 & 1 \\
Job-satisfaction & 1303 & 6.7928 & 2.2937 & 0 & 10 \\
Administration-Modernisation & 1303 & 0.4413 & 0.4967 & 0 & 1 \\
Dissatisfaction-Staff Council & 1303 & 0.2970 & 0.4571 & 0 & 1 \\
\hline
\end{tabular}

Source: author`s calculations (pooled data with 1303 observations containing 336 individuals).

Table A-10: Descriptives, M-Logit Model (Female Career Prospects)

\begin{tabular}{l|rc|ccc}
\hline Variable & Obs & Mean & Std. Dev. & Min & Max \\
\hline Assessment male career prospects & 1297 & 2.0510 & 0.9190 & 1 & 3 \\
\hline Sex & 1297 & 0.3832 & 0.4863 & 1 & 3 \\
Leadership & 1297 & 0.2160 & 0.1453 & 0 & 1 \\
Civil servant & 1297 & 0.5135 & 0.5000 & 0 & 1 \\
Tenure & 1297 & 16.3018 & 10.8698 & 0.166 & 47 \\
Age24 & 1297 & 0.0339 & 0.1811 & 0 & 1 \\
Age25-34 & 1297 & 0.1850 & 0.3885 & 0 & 1 \\
Age35-44 & 1297 & 0.2660 & 0.4420 & 0 & 1 \\
Age45-54 & 1297 & 0.3847 & 0.4867 & 0 & 1 \\
Age55+ & 1297 & 0.1241 & 0.3300 & 0 & 1 \\
Part-time job & 1297 & 0.2922 & 0.4550 & 0 & 1 \\
Temporary contract & 1297 & 0.1333 & 0.3401 & 0 & 1 \\
Job-satisfaction & 1297 & 6.8874 & 2.2100 & 0 & 10 \\
Administration-Modernisation & 1297 & 0.4287 & 0.4951 & 0 & 1 \\
Dissatisfaction-Staff Council & 1297 & 0.2776 & 0.4480 & 0 & 1 \\
\hline
\end{tabular}

Source: author`s calculations (pooled data with 1297 observations containing 334 individuals). 
Table A-11: M-Logit Model Results: Estimation of male career prospects

\begin{tabular}{|c|c|c|c|c|c|}
\hline \multirow[b]{2}{*}{ Variable } & \multicolumn{2}{|c|}{ Coefficients } & \multicolumn{3}{|c|}{ Marginal Effects } \\
\hline & good & bad & good & bad & don' $t$ know \\
\hline \multirow[t]{2}{*}{ Sex } & 0.384 & $3.239 * * *$ & -0.0161 & $0.193^{* * *}$ & $-0.177 * * *$ \\
\hline & $(0.250)$ & $(0.566)$ & $(0.0576)$ & (0.0367) & $(0.0571)$ \\
\hline \multirow[t]{2}{*}{ Leadership } & $1.776^{* *}$ & 1.434 & $0.329 * * *$ & 0.00823 & $-0.337 * * *$ \\
\hline & $(0.850)$ & -1.121 & $(0.110)$ & $(0.0443)$ & $(0.100)$ \\
\hline \multirow[t]{2}{*}{ Civil servant } & $1.021^{* * *}$ & $0.834^{* *}$ & $0.233^{* * *}$ & 0.0124 & $-0.245 * * *$ \\
\hline & $(0.230)$ & $(0.332)$ & $(0.0520)$ & $(0.0122)$ & $(0.0522)$ \\
\hline \multirow[t]{2}{*}{ Tenure } & $0.0650 * * *$ & $0.0414^{* *}$ & $0.0154^{* * *}$ & 0.000321 & $-0.0157 * * *$ \\
\hline & $(0.0152)$ & $(0.0205)$ & $(0.00365)$ & (0.000777) & (0.00365) \\
\hline \multirow[t]{2}{*}{ Age24 } & 0.693 & $1.561 *$ & 0.105 & 0.0789 & -0.184 \\
\hline & $(0.643)$ & (0.904) & $(0.157)$ & $(0.0942)$ & (0.119) \\
\hline \multirow[t]{2}{*}{ Age25-34 } & 0.645 & 0.195 & $0.154^{*}$ & -0.00671 & $-0.148 *$ \\
\hline & (0.399) & (0.588) & $(0.0902)$ & (0.0199) & $(0.0893)$ \\
\hline \multirow[t]{2}{*}{ Age35-44 } & 0.254 & 0.320 & 0.0562 & 0.00797 & -0.0641 \\
\hline & $(0.286)$ & $(0.437)$ & $(0.0679)$ & $(0.0180)$ & $(0.0682)$ \\
\hline \multirow[t]{2}{*}{ Age55+ } & $-0.682 *$ & 0.286 & $-0.172 * *$ & 0.0303 & 0.142 \\
\hline & $(0.378)$ & $(0.506)$ & $(0.0821)$ & $(0.0286)$ & $(0.0880)$ \\
\hline \multirow[t]{2}{*}{ Part-time job } & $-0.476 *$ & -0.382 & $-0.111^{*}$ & -0.00594 & $0.116^{*}$ \\
\hline & $(0.283)$ & $(0.716)$ & $(0.0671)$ & $(0.0273)$ & $(0.0695)$ \\
\hline \multirow[t]{2}{*}{ Temp. contract } & 0.356 & -1.000 & 0.104 & $-0.0345^{* *}$ & -0.0695 \\
\hline & $(0.384)$ & $(0.920)$ & (0.0919) & $(0.0149)$ & $(0.0914)$ \\
\hline \multirow[t]{2}{*}{ Job-satisfaction } & 0.00290 & $-0.202^{* * *}$ & 0.00506 & $-0.00844 * * *$ & 0.00338 \\
\hline & $(0.0535)$ & $(0.0680)$ & (0.0129) & $(0.00287)$ & (0.0129) \\
\hline Administration- & 0.0778 & 0.144 & 0.0163 & 0.00435 & -0.0207 \\
\hline Modernisation & $(0.231)$ & $(0.342)$ & $(0.0550)$ & $(0.0132)$ & $(0.0558)$ \\
\hline Dissatisfaction- & $0.418^{*}$ & $0.833^{* *}$ & 0.0830 & 0.0284 & $-0.111^{*}$ \\
\hline Staff Council & $(0.252)$ & $(0.365)$ & $(0.0578)$ & $(0.0188)$ & $(0.0596)$ \\
\hline Constant & $\begin{array}{l}-1.921^{* * *} \\
(0.588)\end{array}$ & $\begin{array}{l}-3.786^{* * *} \\
(0.863)\end{array}$ & & & \\
\hline Observations & 1303 & 1303 & 1303 & 1303 & 1303 \\
\hline \multicolumn{6}{|c|}{$\begin{array}{l}\log \text { likelihood }(0)=-1258.983, \log \text { likelihood }(5)=-1045.1591 ; \text { Wald } \text { chi }^{2}(26)=130.27 \text {; Prob }>\text { chi }^{2} \\
=.0000 ; \text { Pseudo } \mathrm{R}^{2}=.1689 . \text { Pooled data with Huber-White Estimator, robust standard errors in } \\
\text { parentheses adjusted for } 336 \text { clusters (individuals), } * * * p<0.01, * * \mathrm{p}<0.05, * \mathrm{p}<0.1\end{array}$} \\
\hline
\end{tabular}

Source: author's calculations. 
Table A-12: M-Logit Model Results: Estimation of female career prospects

\begin{tabular}{|c|c|c|c|c|c|}
\hline \multirow[b]{2}{*}{ Variable } & \multicolumn{2}{|c|}{ Coefficients } & \multicolumn{3}{|c|}{ Marginal Effects } \\
\hline & good & bad & good & bad & don't know \\
\hline \multirow[t]{2}{*}{ Sex } & 0.263 & $-1.069 * * *$ & $0.116^{* *}$ & $-0.121^{* * *}$ & 0.00589 \\
\hline & $(0.239)$ & $(0.317)$ & (0.0529) & $(0.0244)$ & $(0.0561)$ \\
\hline \multirow[t]{2}{*}{ Leadership } & $1.695 * *$ & 0.0928 & $0.379 * * *$ & -0.0782 & $-0.301^{* * *}$ \\
\hline & $(0.820)$ & -1.363 & $(0.126)$ & $(0.0591)$ & $(0.114)$ \\
\hline \multirow[t]{2}{*}{ Civil servant } & $0.597 * * *$ & $1.008^{* * *}$ & $0.0909 *$ & $0.0798 * * *$ & $-0.171^{* * *}$ \\
\hline & $(0.215)$ & $(0.278)$ & $(0.0464)$ & $(0.0269)$ & $(0.0489)$ \\
\hline \multirow[t]{2}{*}{ Tenure } & $0.0591 * * *$ & 0.0217 & $0.0132 * * *$ & -0.000691 & $-0.0125 * * *$ \\
\hline & $(0.0142)$ & $(0.0159)$ & $(0.00314)$ & $(0.00155)$ & $(0.00324)$ \\
\hline \multirow[t]{2}{*}{ Age24 } & 0.0949 & $-1.842^{*}$ & 0.0756 & $-0.111^{* * *}$ & 0.0355 \\
\hline & $(0.570)$ & -1.040 & (0.138) & $(0.0257)$ & $(0.141)$ \\
\hline \multirow[t]{2}{*}{ Age25-34 } & 0.251 & $-0.991 * *$ & 0.104 & $-0.0960 * * *$ & -0.00751 \\
\hline & $(0.345)$ & $(0.488)$ & $(0.0809)$ & $(0.0291)$ & $(0.0813)$ \\
\hline \multirow[t]{2}{*}{ Age35-44 } & 0.0456 & -0.362 & 0.0289 & -0.0398 & 0.0108 \\
\hline & $(0.267)$ & $(0.355)$ & $(0.0602)$ & $(0.0308)$ & $(0.0622)$ \\
\hline \multirow[t]{2}{*}{ Age55+ } & -0.254 & $1.049 * *$ & $-0.129 *$ & $0.175^{* *}$ & -0.0461 \\
\hline & $(0.411)$ & $(0.433)$ & $(0.0728)$ & $(0.0692)$ & $(0.0910)$ \\
\hline \multirow[t]{2}{*}{ Part-time job } & $-0.728 * * *$ & $-0.863 * * *$ & $-0.132 * *$ & $-0.0551 * *$ & $0.188^{* * *}$ \\
\hline & $(0.252)$ & $(0.320)$ & $(0.0518)$ & $(0.0256)$ & $(0.0576)$ \\
\hline \multirow[t]{2}{*}{ Temp. contract } & 0.356 & 0.661 & 0.0449 & 0.0605 & -0.105 \\
\hline & (0.335) & $(0.480)$ & $(0.0770)$ & $(0.0624)$ & $(0.0744)$ \\
\hline \multirow[t]{2}{*}{ Job-satisfaction } & 0.0764 & $-0.121 * *$ & $0.0248^{* *}$ & $-0.0173 * * *$ & -0.00748 \\
\hline & $(0.0495)$ & $(0.0601)$ & $(0.0110)$ & $(0.00620)$ & $(0.0114)$ \\
\hline Administration- & 0.0139 & 0.286 & -0.0119 & 0.0315 & -0.0196 \\
\hline Modernisation & $(0.214)$ & $(0.290)$ & $(0.0465)$ & $(0.0292)$ & $(0.0506)$ \\
\hline Dissatisfaction- & 0.315 & $0.766^{* *}$ & 0.0304 & $0.0749 * *$ & $-0.105^{*}$ \\
\hline Staff Council & $(0.247)$ & $(0.301)$ & $(0.0512)$ & $(0.0347)$ & $(0.0567)$ \\
\hline Constant & $\begin{array}{l}-2.001^{* * *} \\
(0.538)\end{array}$ & $\begin{array}{l}-0.882 \\
(0.601) \\
\end{array}$ & & & \\
\hline Observations & 1297 & 1297 & 1297 & 1297 & 1297 \\
\hline \multicolumn{6}{|c|}{ 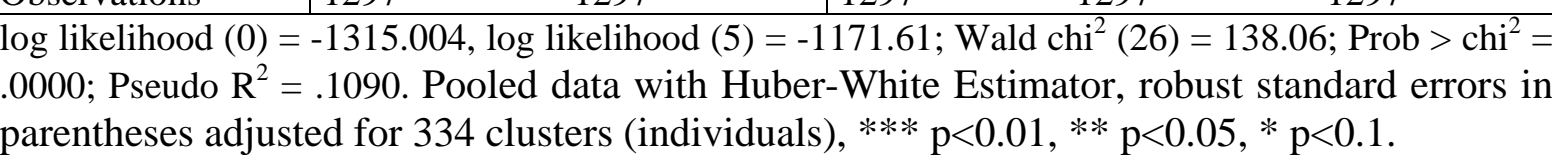 } \\
\hline
\end{tabular}

Source: author's calculations. 


\section{References}

Allmendinger, J., \& Haarbrücker, J. (2013). Lebensentwürfe heute. Wie junge Frauen und Männer in Deutschland leben wollen. Kommentierte Ergebnisse der Befragung 2012. Berlin: WZB Discussion Paper P 2013-002.

Arrow, K.J. (1973). The Theory of Discrimination. In O. Ashenfelter, \& A. Rees, (Eds.), Discrimination in Labor Markets (pp. 3-33). New Jersey: Princeton University Press.

Babcock, L., \& Laschever, S. (2003). Women Don’t Ask: Negotiation and the Gender Divide. Princeton, NJ: Princeton University Press.

Bandura, A. (1997). Self-Efficacy: The Exercise of Control. New York: W.H. Freeman.

Barber, B., \& Odean, T. (2001). Boys Will Be Boys: Gender, Overconfidence, and Common Stock Investment. Quarterly Journal of Economics 116(2), 261-292.

Belley, P., Havet, N., \& Lacroix, G. (2012). Wage Growth and Job Mobility in the Early Career: Testing a Statistical Discrimination Model of the Gender Wage Gap. Bonn: IZA discussion paper 6893. http://ftp.iza.org/dp6893.pdf. Accessed 12 November 2013.

Bertrand, M. (2010). New Perspectives on Gender. In O. Ashenfelter \& D. Card (Eds.), Handbook of Labor Economics, Vol. 4B (pp. 1545-1592). Amsterdam: North Holland. 
Black B., Trainor, M., \& Spencer, J. (1999). Wage Protection Systems, Segregation, and Gender Pay Inequalities: West Germany, the Netherlands and Great Britain. Cambridge Journal of Economics, 23(4), 449-464.

Booth, A. (2007). The Glass Ceiling in Europe: Why are Women Doing Badly in the Labour Market? Swedish Economic Policy Review 14(1), 121-144.

Booth, A., \& Ours, J.C.v. (2008). Job Satisfaction and Family Happiness. Economic Journal, 118(526), 77-99.

Bosak, J., \& Sczesny, S. (2008). Am I the Right Candidate? Self-Ascribed Fit of Women and Men to a Leadership Position. Sex Roles, 58(9-10), 682-688.

Brookes M., Hinks, T., \& Watson, D. (2001). Comparison in Gender Wage Differentials and Discrimination between Germany and the United Kingdom. Labour, 15(3), 393-414.

Busch, A., \& Holst, E. (2008). The Gender Pay Gap in Germany: How Large Is It? Is It Decreasing? How Much Is Due to Workplace Discrimination? In B. Headey \& E. Holst (Eds.), A Quarter Century of Change (pp. 81-86). Berlin: DIW.

Charness, G., \& Gneezy, U. (2011). Strong Evidence for Gender Differences in Risk Taking. Journal of Economic Behavior \& Organization, 83(1), 50-58.

Correll, S.J. (2001). Gender and the Career Choice Process: The Role of Biased SelfAssessments. American Journal of Sociology, 106(6), 1691-1730. 
Croson, R., \& Gneezy, U. (2009). Gender Differences in Preferences. Journal of Economic Literature 47(2), 1-27.

Downs, A. (1957). An Economic Theory of Democracy. New York: Harper \& Brothers.

Ejrnæs, M., \& Kunze, A. (2013). Work and Wage Dynamics around Childbirth. Scandinavian Journal of Economics, 115(3), 856-887.

Fietze, S., Holst, E., \& Tobsch, V. (2011). Germany's Next Top Manager: Does Personality Explain the Gender Career Gap? Management Revue - The international Review of Management Studies, 22(3), 240-273.

Fortin, N. (2008). The Gender Wage Gap among Young Adults in the United States: The Importance of Money vs. People. Journal of Human Resources 43(4), 886-920.

Gneezy, U., Niederle, M., \& Rustichini, A. (2003). Performance in Competitive Environments: Gender Differences. Quarterly Journal of Economics 118(3), 1049-1074.

Goldin, C., \& Rouse, C. (2000). Orchestrating Impartiality: The Impact of »Blind« Auditions on Female Musicians. American Economic Review 90(4), 715-741.

Huber, P.J. (1967). The Behaviour of Maximum Likelihood Estimates under Non-Standard Conditions. In Proceedings of the Fifth Berkeley Symposium on Mathematical Statistics and Probability (pp. 221-233). Berkeley, CA. 
Hubler O. (2005). Is There a Varying Unexplained Gender Wage Gap in Germany? Applied Economics Quarterly, 51(1), 29-48.

Kaiser, L.C. (2007). Gender-Job Satisfaction Differences across Europe: An Indicator for Labour Market Modernization. International Journal of Manpower, 28(1), 75-94.

Kohler-Gehrig, E. (2009). Gender Mainstreaming in der Verwaltung. Kehl: Kehl University of Applied Sciences.

http://www.hs-ludwigsburg.de/dms/dateien/gender\%20mainstreaming\%20in\%20der\%20verwaltung.pdf Accessed November 12, 2013.

Krause, A., Rinne, U., \& Zimmermann K.F. (2012). Anonymous Job Applications in Europe. IZA Journal of European Labor Studies. doi:10.1186/2193-9012-1-5

Leibbrandt, A., \& List, J. (2012). Do Women Avoid Salary Negotiations? Evidence from a Large Scale Natural Field Experiment. NBER Working Paper No. 18511.

Long, S. J. (1997). Regression Models for Categorical and Limited Dependent Variables. London: Sage.

Manning, A., \& Swaffield, J. (2008). The Gender Gap in Early-Career Wage Growth. Economic Journal, 118(530), 983-1024. 
Niederle, M., \& Vesterlund, L. (2007). Do Women Shy Away from Competition? Do Men

Compete too Much? Quarterly Journal of Economics 122(3), 1067-1101.

OECD (2012). Closing the Gender Gap. Act now. Paris: OECD Publishing.

Phelps, E. (1972). The Statistical Theory of Racism and Sexism. American Economic Review, 62(4), 659-661.

Schreiber, U. (2013). Worldwide Index of Women as Public Sector Leaders. Opening Doors for Women Working in Government. New York: Ernst \& Young.

Sieverding, M. (2003). Frauen unterschätzen sich: Selbstbeurteilungs-Biases in einer simulierten Bewerbungssituation. Zeitschrift für Sozialpsychologie, 34(3), 147-160.

Sieverding, M. (2009). 'Be Cool!': Emotional Costs of Hiding Feelings in a Job Interview. International Journal of Selection \& Assessment, 17(4), 391-401.

Spencer, S., Steele, C. \& Quinn, D. (1999). Stereotype Threat and Women's Math Performance. Journal of Experimental Social Psychology, 35(1), 4-28.

White, H. (1980). A Heteroskedasticity-Consistent Covariance Matrix Estimator and a Direct Test for Heteroskedasticity. Econometrica, 48(4), 817-838.

White, H. (1982). Maximum Likelihood Estimation of Misspecified Models. Econometrica, 50(1), 1-26. 